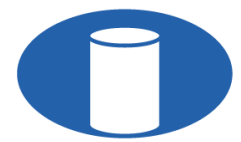

IBRACON Structures and Materials Journal

Revista IBRACON de Estruturas e Materiais

ORIGINAL ARTICLE

\title{
A simplified numerical approach to the evaluation of residual shaft friction induced by concrete curing in drilled shafts on granular soils
}

\section{Uma abordagem numérica simplificada para a avaliação do atrito lateral induzido pela cura do concreto em estacas escavadas em solos granulares}

\author{
Augusto Bopsin Borges ${ }^{\mathrm{a}}$ \\ Renato Vaz Linn ${ }^{\text {a }}$ \\ Fernando Schnaid ${ }^{\mathrm{b}}$ \\ Samir Maghous ${ }^{\mathrm{a}}$
}

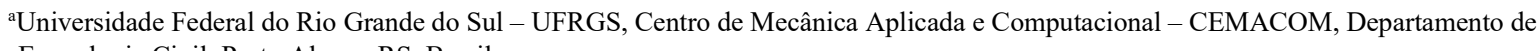
Engenharia Civil, Porto Alegre, RS, Brasil

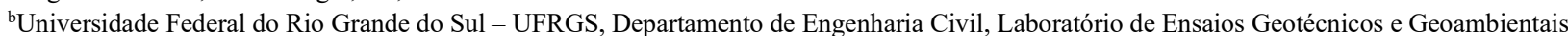
- LEGG, Porto Alegre, RS, Brasil

Received 26 August 2019

Accepted 13 February 2020

\begin{abstract}
Conventional interpretation procedures of load tests on instrumented piles rely upon measurements of strains that assume as zero for strains measured at the instant immediately before starting the test as reference configuration. However, some experimental evidence shows that concrete in drilled shafts undergoes strains induced by the curing process comparable in magnitude to the strains measured during the load tests. It is therefore expected that mobilization of shaft friction takes place before the load test. Several authors have performed experimental and numerical analyses aiming to quantify the influence of those pre-load test concrete volumetric strains on the measured bearing capacity using different approaches. The present work aimed to establish a reference framework for the existing and future works on this topic. In order to assess the influence of concrete strains induced by curing process on the shaft friction before the start of the load tests in drilled shafts, several finite element numerical simulations are performed, considering the thermal, autogenous and drying strains. The analyses consider concrete as an isotropic linear-elastic material and the soil as an elastic-plastic material using the Mohr-Coulomb constitutive model natively implemented in the software ABAQUS. The results are interpreted focusing on the relevancy on the bearing capacity and load distribution along drilled shafts considering or not the strains induced by concrete curing.
\end{abstract}

Keywords: residual stresses, numerical modeling, shaft friction, design parameters, drilled shafts.

Resumo: Procedimentos convencionais de interpretação de provas de carga em estacas escavadas instrumentadas baseiam-se em medidas de deformações para as quais assume-se como configuração de referência e deformação nula o instante imediatamente anterior ao início da prova de carga. No entanto, algumas evidências experimentais mostram que o concreto, em estacas escavadas, apresenta deformações devidas ao processo de cura do concreto de magnitude comparável às medidas durante as provas de carga. Portanto, pode-se esperar que a mobilização de atrito lateral comece a se desenvolver antes mesmo do início das provas de carga. Alguns autores através de procedimentos experimentais e análises numéricas buscaram quantificar a influência de tais deformações volumétricas do concreto em etapa anterior à prova de carga na capacidade de carga das estacas através de diferentes abordagens. O presente trabalho busca estabelecer um quadro de referência sobre o tema para trabalhos existentes e futuros. Buscando avaliar a influência das deformações do concreto induzidas pelo o processo de cura no atrito lateral desenvolvido antes de provas de carga em estacas escavadas, foram realizadas simulações numéricas por elementos finitos considerando deformações térmicas, autógenas e por secagem do concreto. As análises foram realizadas considerando o concreto como material elástico linear e isótropo e o solo como elastoplástico seguindo o modelo constitutivo de Mohr-Coulomb, nativamente implementado no software ABAQUS. Os resultados são interpretados

Corresponding author: Augusto Bopsin Borges. E-mail: augusto.borges@ufrgs.br

Financial support: CAPES; CNPq (process number 130119/2018-0).

Conflict of interest: Nothing to declare.

This is an Open Access article distributed under the terms of the Creative Commons Attribution License, which permits unrestricted use, distribution, and reproduction in any medium, provided the original work is properly cited. 
focando na relevância das deformações de cura para a capacidade de carga e distribuição de carga ao longo de estacas escavadas em solo granular, considerando ou não as deformações no concreto devidas ao seu processo de cura.

Palavras-chave: tensões residuais, modelagem numérica, atrito lateral, parâmetros de projeto, estacas escavadas.

How to cite: A. B. Borges, R. V. Linn, F. Schnaid, and S. Maghous, "A simplified numerical approach to the evaluation of residual shaft friction induced by concrete curing in drilled shafts on granular soils," Rev. IBRACON Estrut. Mater., vol. 13, no. 5, e13505, 2020, https://doi.org/10.1590/S1983-41952020000500005

\section{INTRODUCTION}

The consideration of shaft friction mobilized during the installation of driven piles, prior to load test procedures, is a fundamental issue in foundation engineering [1]. In the context of drilled shafts, variations of normal stresses as well as associated mobilized shaft friction at the pile-soil interface, prior to external load application, should be also properly evaluated [2]. These distributions are expected to be notably governed by concrete volumetric shrinkage or expansion strains during pre-load test phase.

Measurements during pre-load stage of instrumented pile load tests revealed significant variations in the strain profile, which would alter the reference configuration for the instrumentation zero readings [3]-[5]. In particular, Viggiani and Vinale [4] and Pennington [5] reported strain measurements along the shaft of instrumented piles, illustrated in Figure 1 and Figure 2, where negative strains refer to swelling, while positive strains reflect shrinkage. The results emphasized that the concrete undergoes significant volumetric shrinkage strains in a pre-load test phase.

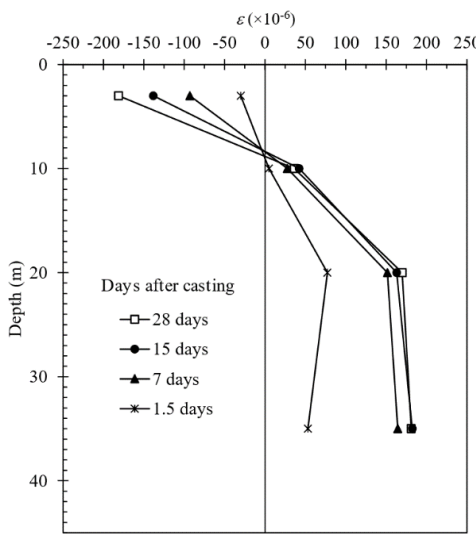

(a)

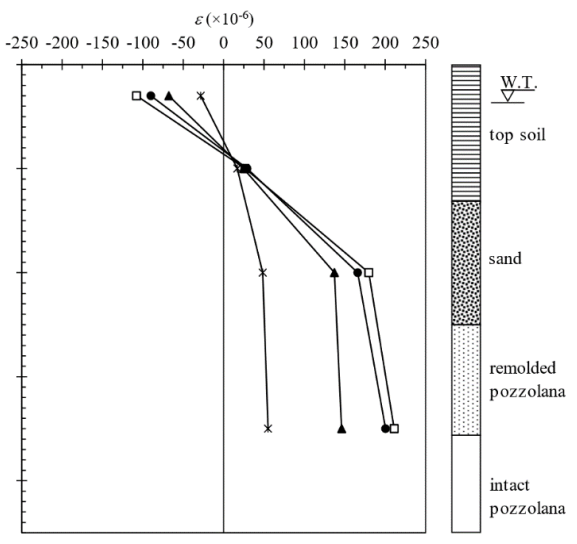

(b)

Figure 1. Strain measurements along the depth for two different drilled shafts; (a) pile A and (b) pile C [4].

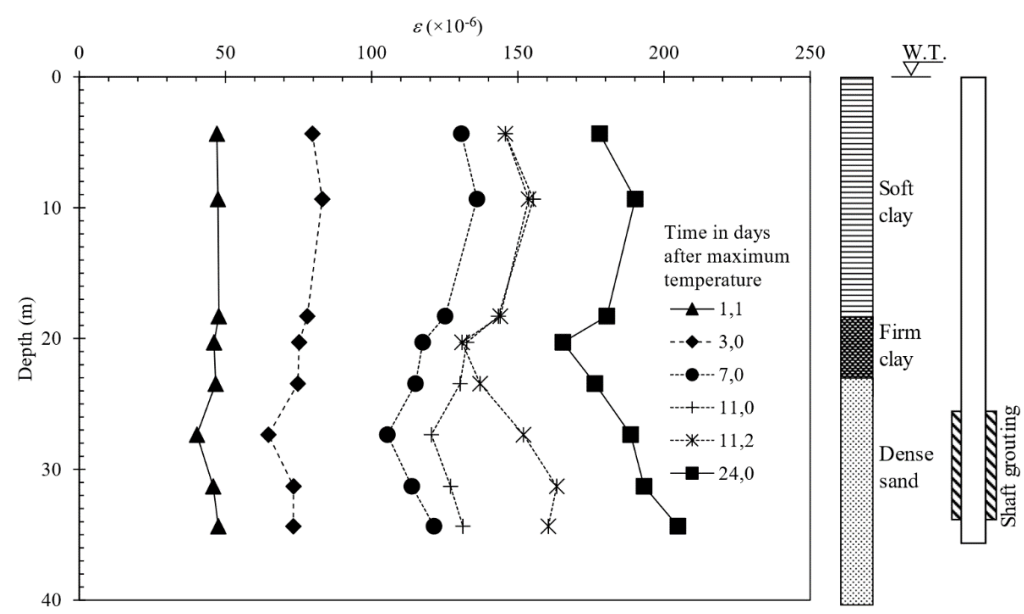

Figure 2. Strain measurements during the curing period for a drilled pile with $1.5 \mathrm{~m}$ diameter [5]. 
Based on strain measurements together with temperature rising profiles induced by the concrete curing process recorded immediately after concrete casting in large diameter drilled shafts, Pennington [5] estimated the mobilized shaft friction. Calculated values for the unit shaft friction for both residual stresses prior to test and during pile load tests are shown in Figure 3. For residual shaft friction, the volumetric strains in the pile due to the curing induced contraction in the upper portion of the pile, generating downward relative movements and consequently positive shaft friction. On the contrary, the residual shaft friction is negative along the lower part. Although it may appear that the average of the residual stresses tends to a vanishing value, it is however expected to modify the equilibrium stress distribution along the pile during loading.

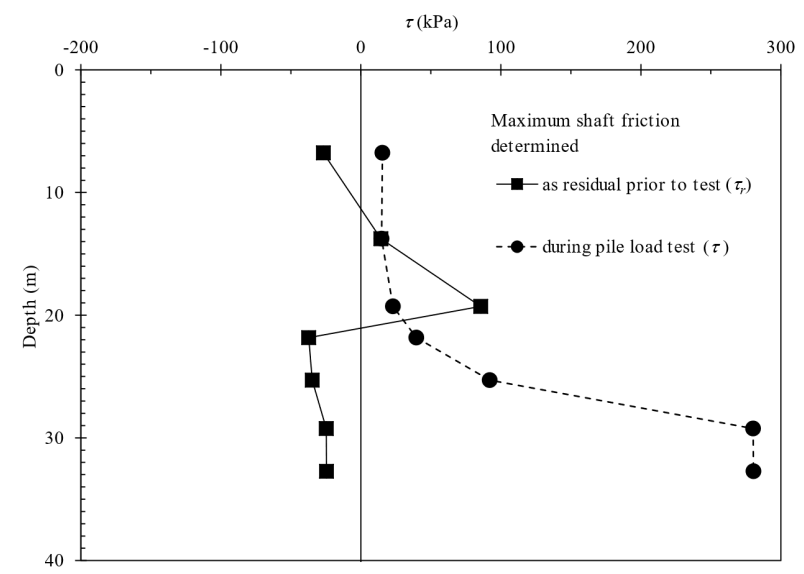

Figure 3. Comparison of residual shaft friction with shaft friction establish from load test for a $1.5 \mathrm{~m}$ diameter pile [5].

It comes from the above experimentally based analyses that the concrete curing phenomena can be viewed as an important component of pile-soil interaction, thus affecting the mechanical state in the soil around the pile.

Concerning the available shaft resistance in drilled shafts, rational procedures for its evaluation in granular soils are classically based on the assumption that the shaft friction mobilized at the pile-soil interface follows the linear Coulomb friction model. In the simplified framework in which the residual stresses are disregarded and the geostatic state of stresses is preserved, the shaft friction at any depth $z$ along the pile-soil interface may be expressed as:

$\tau(\mathrm{z})=\sigma_{\mathrm{h}}^{\prime}(\mathrm{z}) \tan \delta(\mathrm{z})=\mathrm{K}_{\mathrm{s}}(\mathrm{z}) \sigma_{\mathrm{v} 0}^{\prime}(\mathrm{z}) \tan \delta(\mathrm{z})=\beta(\mathrm{z}) \sigma_{\mathrm{v} 0}^{\prime}(\mathrm{z})$

It comes from the above experimentally based analyses that the concrete curing phenomena can be viewed as an important component of pile-soil interaction, thus affecting the mechanical state in the soil around the pile.

Concerning the available shaft resistance in drilled shafts, rational procedures for its where $\tau$ is the unit shaft friction, $\sigma_{h}^{\prime}$ is the acting effective horizontal stress, $\delta$ is the interface friction angle, $\sigma_{v 0}^{\prime}$ is the effective initial vertical stress, $K_{s}=\tau /\left(\sigma_{v 0}^{\prime} \tan \delta\right)=\sigma_{h}^{\prime} / \sigma^{\prime}{ }_{v 0}$ is a measure of the acting lateral earth pressure, and $\beta=\tau / \sigma_{v 0}^{\prime}=K_{s} \tan \delta$ is a shaft friction design parameter.

Although this assumption might appear at first glance questionable from the mechanical viewpoint, Burland [6] highlighted that this expression represents a simple and logical starting point evaluating the pile shaft friction from well-established soil mechanics properties.

Parameters $K_{s}(z)$ and $\beta(z)$ seek to encompass in a global manner the essential soil characteristics and associated uncertainties in pile analysis and design. This formulation takes implicitly into account the stress history of the soil, mobilized friction angle and pile-soil interface properties, grain-size distribution, as well as changes in lateral stresses induced by pile installation procedures and straining at the pile-soil interface caused by concrete curing process. To illustrate the importance given to stress history and related $K_{0}$ profile Mayne and Kulhawy [7] and Kulhawy [8], using $K_{s}=K_{0}$ for $\beta$, considers that if overconsolidation is disregarded at shallow depths (constant value of $K_{0}$ - Normally Consolidated soil), the respective $\beta$ profiles would also be constant with depth (dashed lines in Figure 4). Considering $\delta$ constant with depth, one can note that the main influent factor on the increase of $\beta$ at shallow depth should precisely be the preexisting $K_{0}$ profile. 


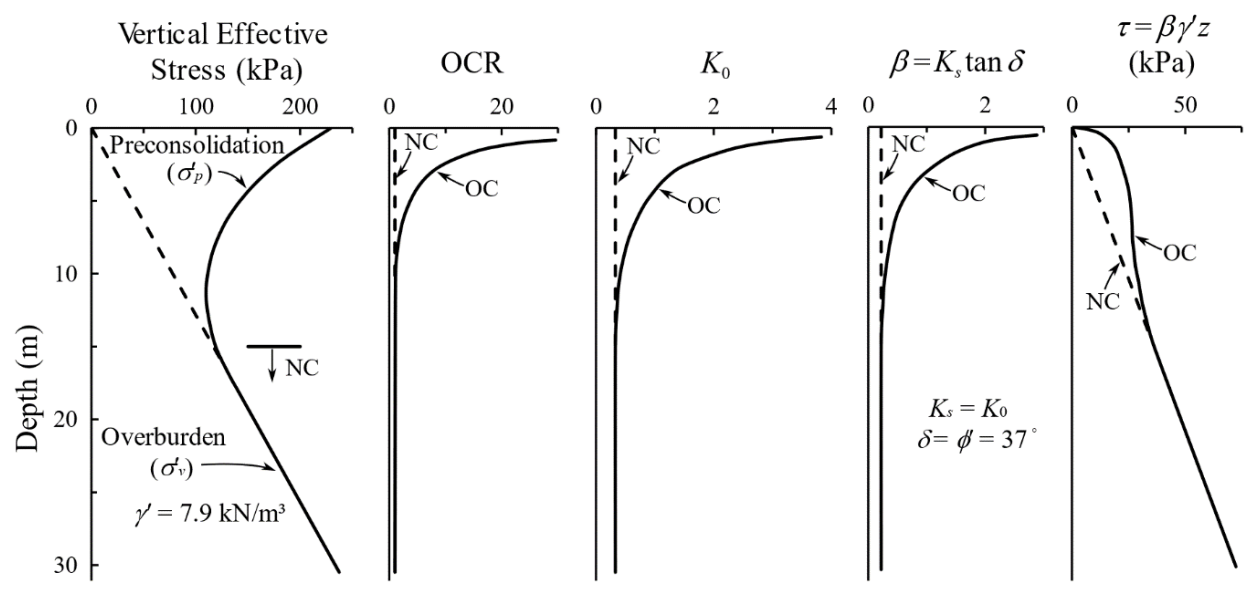

Figure 4. Example illustrating the principles of shaft resistance [8].

The mobilized interface friction angle $\delta(z)$ has been the subject of several studies pointing out its dependence on the pile-soil interface roughness. Typical $\delta(z)$ values range from the critical state friction angle $\phi^{\prime}{ }_{c r i t}$, for smoothed interfaces, to the peak friction angle $\phi_{\text {peak }}^{\prime}$, for rough interfaces. Drilled shafts always exhibit high roughness at the pile-soil interface and failure yielding is likely to occur in the soil mass, following a simple shear mode governed by $\phi_{\text {crit }}^{\prime}$ angle.

According to Kulhawy [8] and [9], the typical profiles for $\beta$ and $K_{s}$ decreasing with depth (Figure 4 ) can be explained as reflecting the reduction in $K_{0}$ with depth together with the decrease in soil friction angle as confining stresses increase.

Focusing the analyses on the effects induced on the shaft friction of floating drilled shafts embedded in granular soils, in the pre-load test stage, Mascarucci [10] and Mascarucci et al. [11] performed axisymmetric numerical simulations in axially load piles considering curing strains coupled with evolving stiffness during the curing process. Both approaches used the standard finite-difference FLAC 2D software with a strain softening behavior for the interface constitutive model and a Strain Softening Model for the soil [12]. These studies emphasized that restarting the strain measurements in instrumented piles immediately before the load test would introduce significant errors in the distribution of shaft friction along the pile-soil interface.

Based on a simplified but consistent formulation, the present work aims at presenting a reference framework for existing and future numerical analyses. Restricting the subsequent analysis to concrete drilled shaft embedded in granular soils, this work focuses on the effects induced on the shaft friction by concrete curing strains during pre-load test stage. In that respect, the analysis is undertaken in the context of fully drained conditions, indicating that pore pressure effects are not relevant for the proposed approach.

\section{Numerical Model}

As the problem of cylindrical piles axially loaded in homogeneous soil (usual configuration for drilled shafts) complies with the revolution symmetry with respect to the pile axis, axisymmetric modeling is adopted for bearing capacity analyses. The overall dimensions of the model in terms of the pile length $L$ and pile diameter $D$, together with model boundary conditions are shown in Figure 5. The different zones in Figure 5 were established for mesh control and refinement. The typical finite element model discretization used is shown in Figure 6. Four-node axisymmetric quadrilateral elements with bilinear displacement CAX4, available in the ABAQUS finite element library, were used for both pile and soil. Due to the roughness classically observed along drilled pile shaft [13], resulting from drilling and casting concrete processes, a perfect bonding condition is assumed at the pile-soil interface.

The width and height of the geometric model are respectively fixed as $B=25 D$ and $H=2.5 L$, according to standard discretization used in foundation analyses [14]. As regards material constitutive characteristics, concrete was modeled as an isotropic linear-elastic material, with Young's modulus $E_{c}=30 \mathrm{GPa}$ (corresponding approximately to $f_{c k}=30 \mathrm{MPa}[15]$ ) and Poisson's ratio $v_{c}=0.2$, whereas the behavior of the homogeneous soil is described by means of an non associated elasto-plastic Mohr-Coulomb model, with Young's modulus $E_{s}=50 \mathrm{MPa}$, Poisson's ratio $v_{s}=0.2$, friction angle $\phi=29^{\circ}$ and dilatancy angle $\psi=1^{\circ}$. Physical material parameters of Ottawa sand defined in Han et al. [16] as specific gravity $G_{s}=2.65$, minimum void ratio $e_{\min }=0.48$ and maximum void ratio $e_{\max }=0.78$ were used. The value of the coefficient of earth pressure at rest is fixed to $K_{0}=0.4$. 


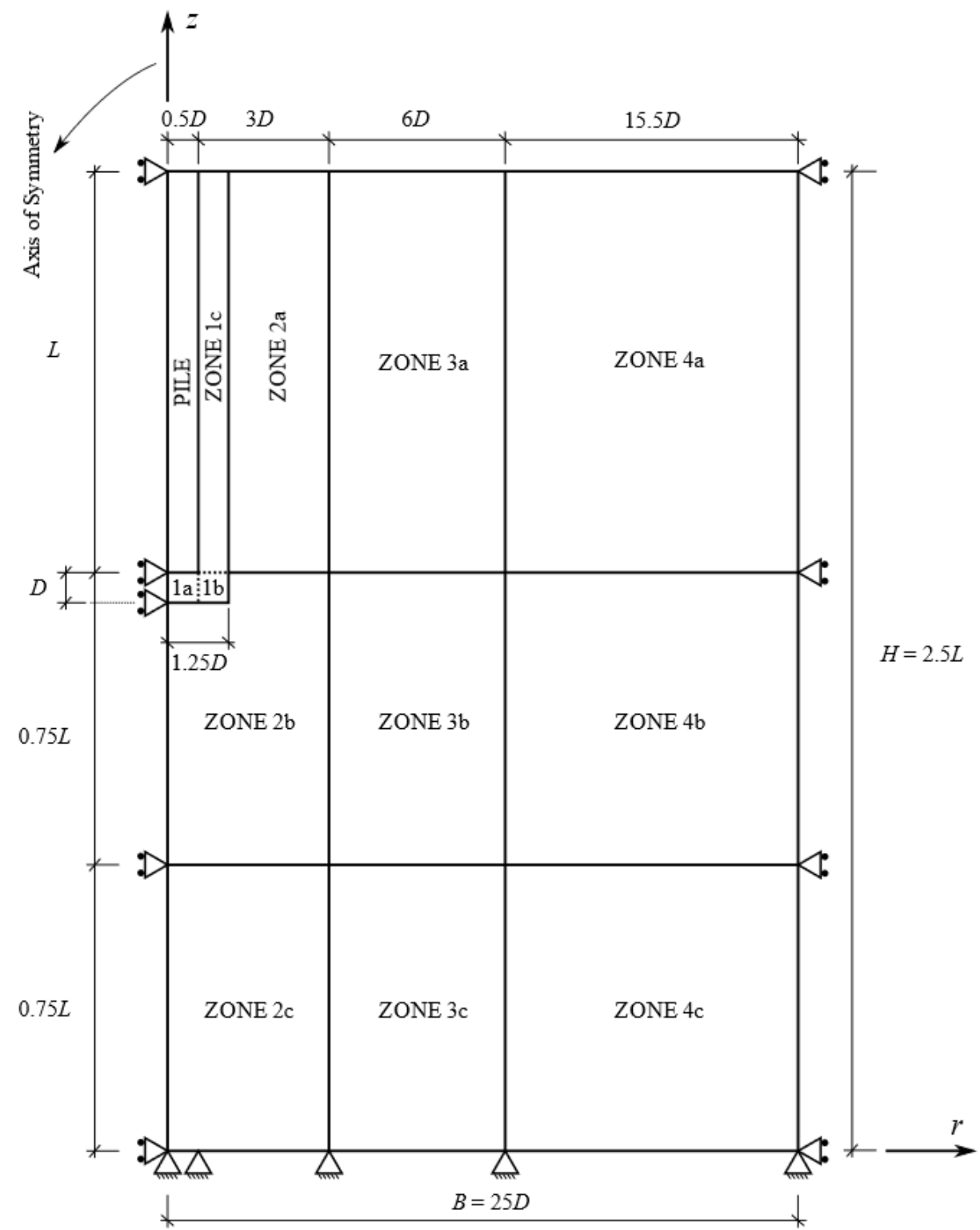

Figure 5. Global dimensions and boundary conditions in $r-z$ plane.

For the purpose of numerical model validation, a convergence analysis was performed to define the finite element mesh configuration, comparing the results obtained using the model with those presented by Han et al. [16] in analogous analysis involving a $300 \mathrm{~mm}$ diameter and $10 \mathrm{~m}$ long pile. Dry sand conditions were assumed, with relative density $I_{D}=50 \%$, corresponding to a void ratio $e=0.63$ and an effective specific weight $\gamma^{\prime}=15.95 \mathrm{kN} / \mathrm{m}^{3}\left(\right.$ density $\left.d=1,625.77 \mathrm{~kg} / \mathrm{m}^{3}\right)$. For sake of simplicity, the same density was used for both soil material and pile concrete in all subsequent analyses.

The numerical simulations, including the validation analysis, were performed following a three steps procedure (Figure 7): geostatic step, in which the dead load is applied by acceleration of gravity $g=9.81 \mathrm{~m} / \mathrm{s}^{2} \mathrm{using}$ an automatic time increment scheme under small deformations conditions; curing process step, for pile thermal volumetric strains that are imposed following fib Model Code recommendations [17]; and load test step, in which a prescribed displacement of $w=10 \% D$ is incrementally applied.

For the preliminary numerical validation and convergence analysis, the concrete step curing_process was not accounted for, disregarding curing strains. Comparison of model predictions obtained herein and results from Han et al. [16] are shown in Figure 8. The numerical values for ultimate total $\left(Q_{u l t}\right)$, lateral $\left(Q_{l, u l t}\right)$ and base $\left(Q_{b, u l t}\right)$ resistances are presented in Table 1 . The perfect agreement observed between the present simulations and results provided in Han et al. [16] validate the proposed modeling. 


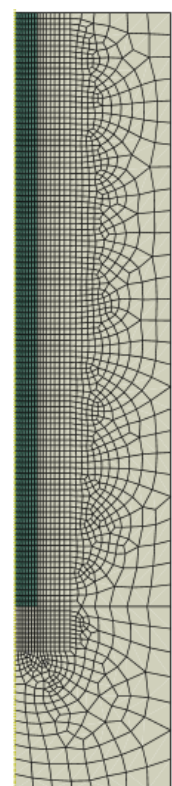

(c)
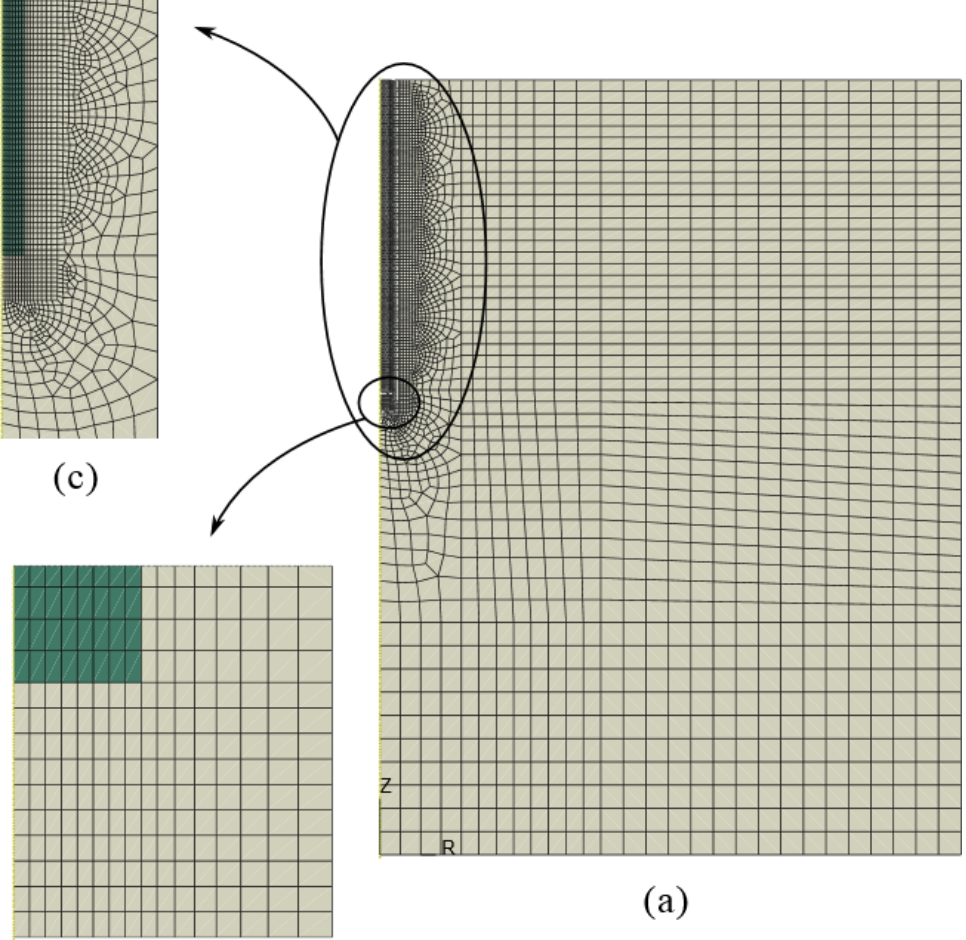

(a)

(b)

Figure 6. Finite element mesh used for model geometry (a), detailed mesh at pile tip (b) and detailed mesh at pile shaft (c).

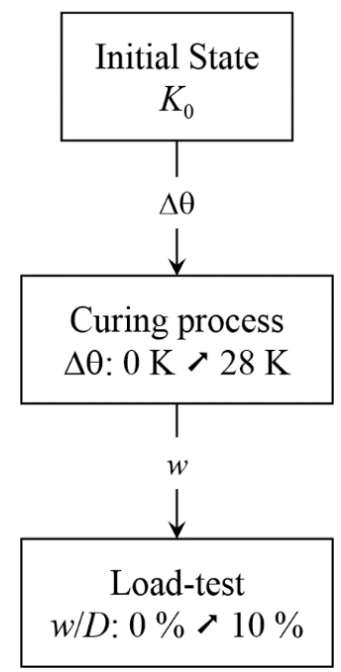

Figure 7. General scheme of the analyses. 


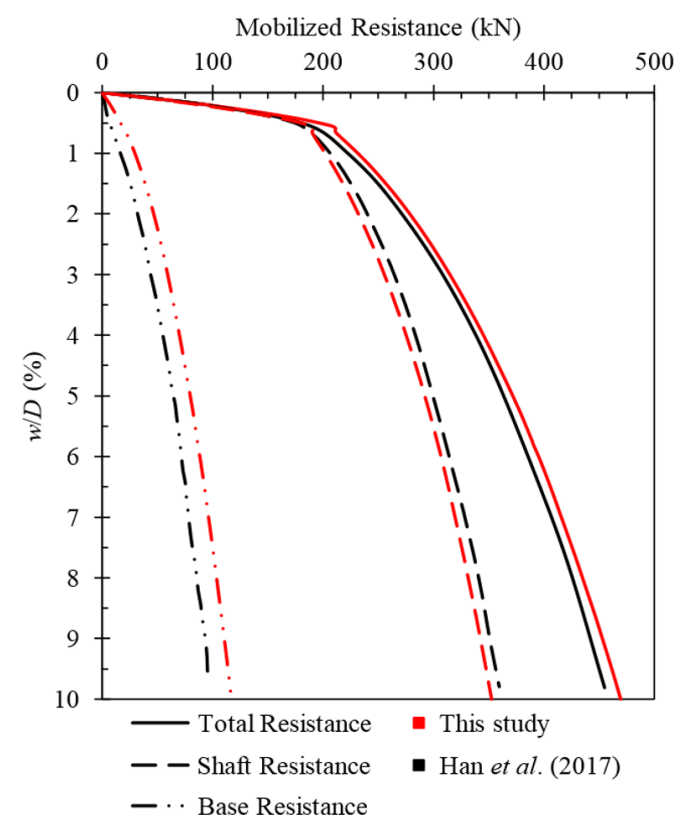

Figure 8. Results for the mobilized resistance as a function of the relative settlement of the pile head.

Table 1. Ultimate total, lateral and base resistances $(w / D=10 \%)$.

\begin{tabular}{ccc}
\hline Resistance component & Present study & Han et al. [16] \\
\hline$Q_{u l t}(\mathrm{kN})$ & 463.85 & 454.93 \\
\hline$Q_{l, u l t}(\mathrm{kN})$ & 352.57 & 359.49 \\
\hline$Q_{b, u l t}(\mathrm{kN})$ & 114.80 & 96.19 \\
\hline
\end{tabular}

\section{Numerical assessment of residual shaft friction}

A The purpose of this section is to perform a series of finite element simulations to investigate the effects of concrete curing on the mobilized shaft friction of drilled shafts. Keeping the pile length fixed to $L=20 \mathrm{~m}$, assessment of pile slenderness $L / D$ effects were investigated varying the pile diameters in the range of $0.5 \mathrm{~m}$ to $1.5 \mathrm{~m}(L / D$ ranging from 40 to 13.33$)$ for both dry $(S=0)$ and saturated $(S=1)$ sand. Appropriate effective specific unit weight of $\gamma^{\prime}=15.95 \mathrm{kN} / \mathrm{m}^{3}\left(d=1,625.77 \mathrm{~kg} / \mathrm{m}^{3}\right)$ and $\gamma^{\prime}=9.93 \mathrm{kN} / \mathrm{m}^{3}\left(d=1,012.27 \mathrm{~kg} / \mathrm{m}^{3}\right)$ were respectively adopted for the dry ad saturated conditions. General characteristics of the numerical finite element discretization used in each configuration are summarized in Table 2.

Table 2. Numerical finite element discretization used in the analyses.

\begin{tabular}{|c|c|c|c|c|c|}
\hline Analysis & $S$ & Pile Diameter & $L / D$ & $\begin{array}{c}\text { Number of elements } \\
- \text { soil }\end{array}$ & $\begin{array}{c}\text { Number of elements } \\
\text { - pile }\end{array}$ \\
\hline SIM-01 & $0 \%$ & \multirow{2}{*}{$0.50 \mathrm{~m}$} & \multirow{2}{*}{40} & \multirow{2}{*}{9,676} & \multirow{2}{*}{2,560} \\
\hline SIM-02 & $100 \%$ & & & & \\
\hline SIM-03 & $0 \%$ & \multirow{2}{*}{$1.00 \mathrm{~m}$} & \multirow{2}{*}{20} & \multirow{2}{*}{4,880} & \multirow{2}{*}{1,280} \\
\hline SIM-04 & $100 \%$ & & & & \\
\hline SIM-05 & $0 \%$ & \multirow{2}{*}{$1.50 \mathrm{~m}$} & \multirow{2}{*}{13.33} & \multirow{2}{*}{3,359} & \multirow{2}{*}{856} \\
\hline SIM-06 & $100 \%$ & & & & \\
\hline
\end{tabular}

\section{Simulation of concrete curing process}

Due to microstructural mechanisms, concrete shrinkage is classically separated into autogenous and drying shrinkage [17], [18]. Hydration of the cement compounds involves mainly exothermic reactions that raise the temperature of the concrete mass (Figure 9), inducing thermal volumetric strains $\left(\varepsilon_{t h}\right)$. The total volumetric strains $\left(\varepsilon_{c s}\right)$ 
resulting from the concrete curing process $\varepsilon_{c s}$ is a sum of those three strain components (Equation 2): autogenous shrinkage $\varepsilon_{c a s}$, drying shrinkage $\varepsilon_{c d s}$, and thermal shrinkage $\varepsilon_{t h}$.

$\varepsilon_{\mathrm{cs}}=\varepsilon_{\mathrm{cas}}+\varepsilon_{\mathrm{cds}}+\varepsilon_{\mathrm{th}}$

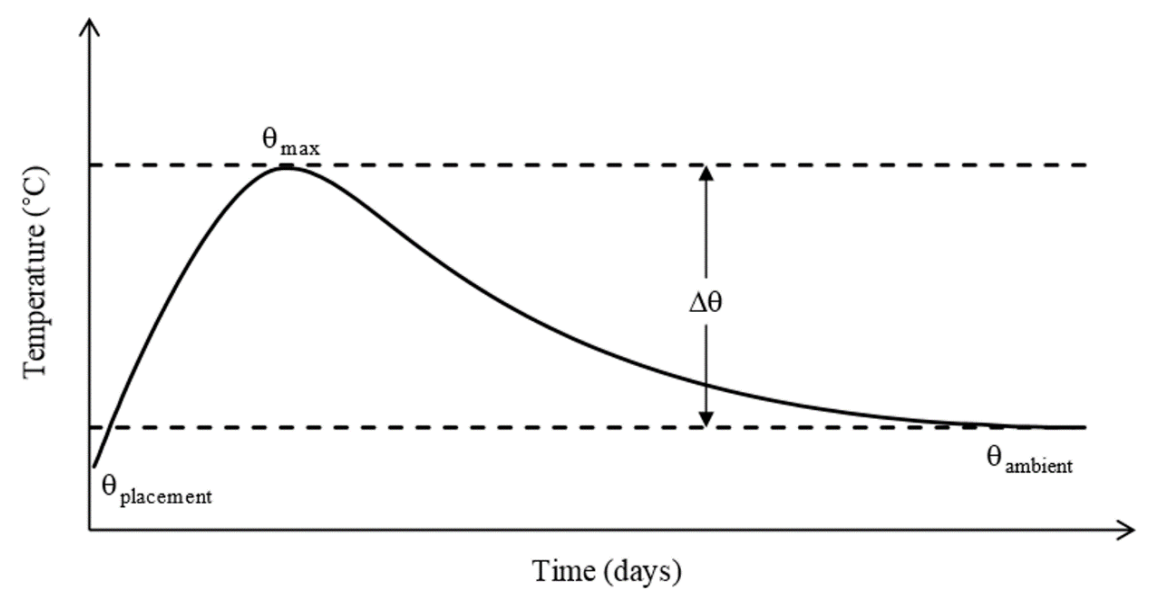

Figure 9. Temperature change with time. Adapted from Mehta and Monteiro [19].

The development of the autogenous and drying shrinkage during the curing period of 28 days was calculated following fib Model Code recommendations [17]. Physically, these shrinkage components are a function of factors such as water-cement ratio, cement type and content, strength class, environmental conditions, type of aggregate, among others. In the model, these components are computed using the concrete compressive strength as a design parameter accounting at macroscopic scale for concrete strength class, aggregate type, cross-section geometry, relative humidity and duration of drying. The thermal shrinkage resulting from the temperature change $\Delta \theta$ induced by curing process is calculated from concrete thermal expansion, with a thermal expansion coefficient $\alpha_{c}=1 \times 10^{-5} \mathrm{~K}^{-1}$ as: [19]

$\varepsilon_{\mathrm{th}}=\alpha_{\mathrm{c}} \Delta \theta$

where $\Delta \theta \in[0 \mathrm{~K}, 28 \mathrm{~K}]$ is considered in the analysis.

The distribution of temperature variation raising in concrete during the curing varies with depth and is heteronomous within the cross-section of the pile. For simplicity, however, a spatially uniform temperature profile was assumed, using the temperature profile measured in a large diameter drilled shaft by Pennington [5] (Figure 10), for the entire pile. The temperature is assumed to remain constant after 20 days, with further curing strains calculated by fib Model Code recommendations [17].

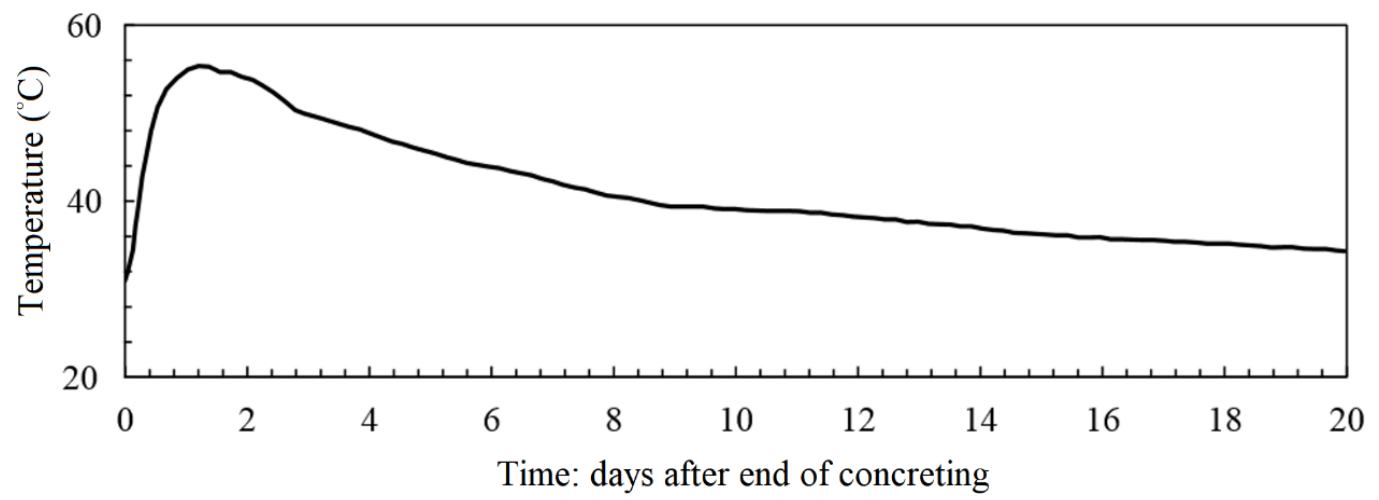

Figure 10. Experimental profile of temperature change with time [5]. 
In the thermal analysis it is assumed that concrete sets at maximum temperature, so that the development of differential strains between the contracting pile and the soil can be estimated from this reference time. Strains due to the thermal expansion of the pile before the maximum temperature is reached are therefore disregarded, as well as associated loading that is transferred to the soil.

Note that, in the numerical simulation of the curing process, the evolution of the strains in the concrete is imposed in the curing process step. The temperature change $\Delta \theta$ was used as a kinematic time for assessing the mechanical state of the system, since material properties can be expressed as a function of temperature through a thermo-mechanical coupling. To meet the model of thermal strains proposed in fib recommendations, as displayed in Figure 11, the curing strains that are actually imposed to the pile have been evaluated considering an appropriate fictitious non-linear coefficient of expansion $\alpha_{c, f i c}$ for each $\Delta \theta \in[0 \mathrm{~K}, 28 \mathrm{~K}]$ by means of Equation 3.

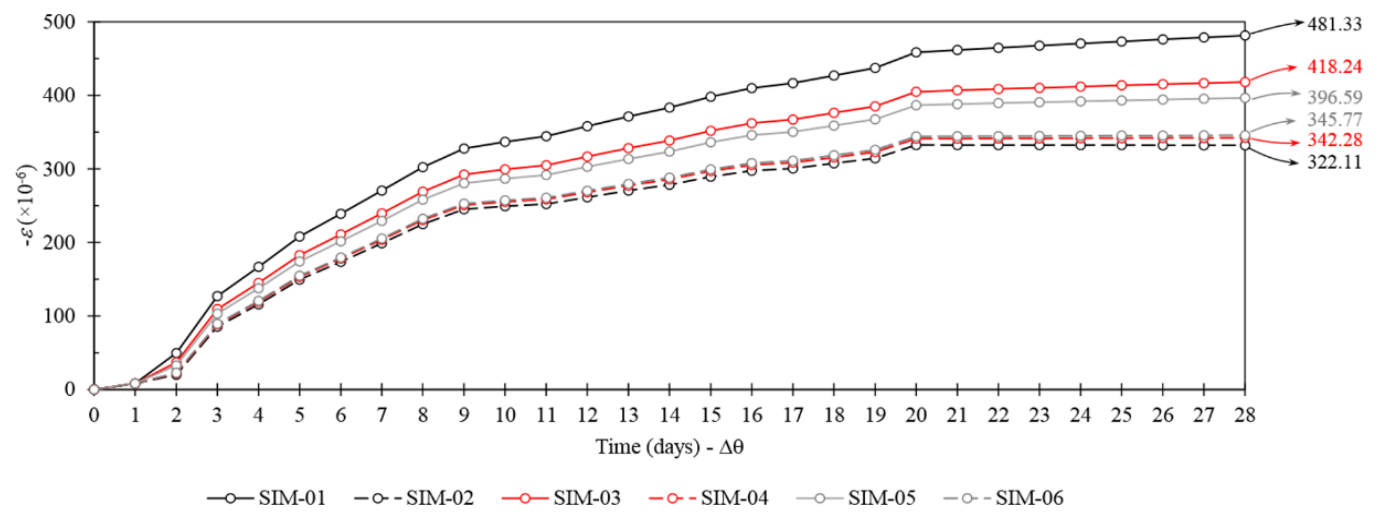

Figure 11. Imposed curing strains in the curing process step.

\section{RESULTS AND DISCUSSION}

In the load_test step, a total displacement of $10 \% D$ was prescribed at the pile head, linearly applied during the time step. Although this maximum value of displacement has been adopted to ensure the validity of small strain framework, it is often assumed a representative of ultimate state in foundation design. For comparison purposes, numerical simulations were performed with and without accounting for the curing process for each selected slenderness $L / D$ and saturation condition. The numerical load test simulation consisted in applying incrementally a total displacement of $10 \% D$ to the pile head after completion of the curing process.

The mobilized shaft friction $\tau$ along depth obtained from the simulations of the six different configurations defined in Table 2 are presented in Figure 12. Results correspond to the ultimate pile load obtained for $10 \% D$ total displacement. Solid lines represent simulations carried out with account for concrete curing and dashed lines stands for simulation disregarding this process (suppressing the curing process step).

In Figure $12, \tau_{\text {real }}$ refers to shaft friction computed from the initial reference configuration when concrete curing starts, whereas $\tau_{\text {virtual }}$ is computed considering the configuration reached after completion of the curing process (immediately before the start of the load test) as the reference configuration. Deviation between $\tau_{\text {real }}$ and $\tau_{\text {virtual }}$ can be quantified by means of:

$\tau_{\mathrm{r}}=\tau_{\text {real }}-\tau_{\text {virtual }}$

which represents the error $\tau_{r}$ introduced when volumetric concrete curing strains are disregarded in the analysis.

The most important feature of numerical predictions lies in the fact that the actual distribution in shaft friction $\tau_{\text {real }}$ at ultimate state coincides with the values calculated when the curing process is disregarded. This fact is consistent with general theorems of plasticity stating that the stress field at ultimate state is insensitive to initial stress distribution state [20], [21].

In addition, Figure 12 emphasize that significant errors can be induced when the unit shaft friction is evaluated based on the so-called virtual reference configuration. This is mainly explained as follows. The volumetric strains in the pile due to the curing induce contraction in the whole pile, generating downward relative movements in the upper part of the pile and upward relative movements in its lower part. These relative movements between the contracting 
pile and the adherent soil elements mobilize shaft friction in the soil elements (considered positive upwards and negative downwards). It is therefore demonstrated that "zeroing" the instruments immediately before starting a load test may reveal mechanically inconsistent for stress pile analysis.
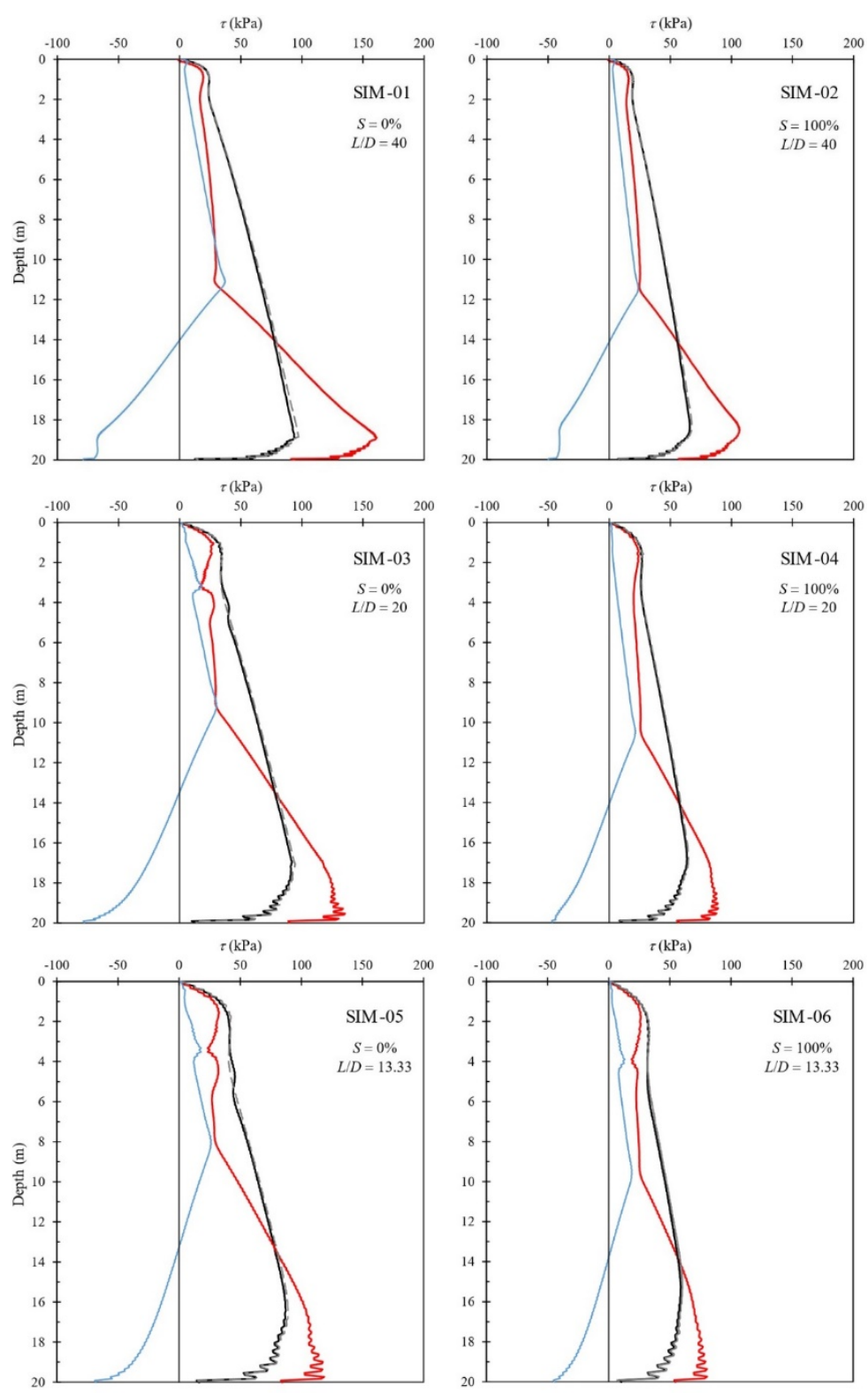

- - Shaft friction without imposition of curing strains

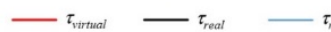

Figure 12. Distribution of unit shaft friction on soil elements adjacent to the pile for $10 \% D$ total displacement: $L / D=40$ (SIM- 01 and SIM-02), $L / D=20$ (SIM-03 and SIM-04), and $L / D=13.33$ (SIM-05 and SIM-06).

In order to observe the impact of the concrete curing strains on the total load distribution along the pile at ultimate state, normalized load distribution curves are shown in Figure 13 for the cases described in Table 2.

It is observed from curves in Figure 13 that although the normalized load distribution computed from both real and virtual conditions differ along the shaft, the corresponding values of base resistance are close to each other. It implies that the predicted ultimate shaft and base load components are not affected by the procedure adopted regarding the reference configuration in instrumented load tests. 

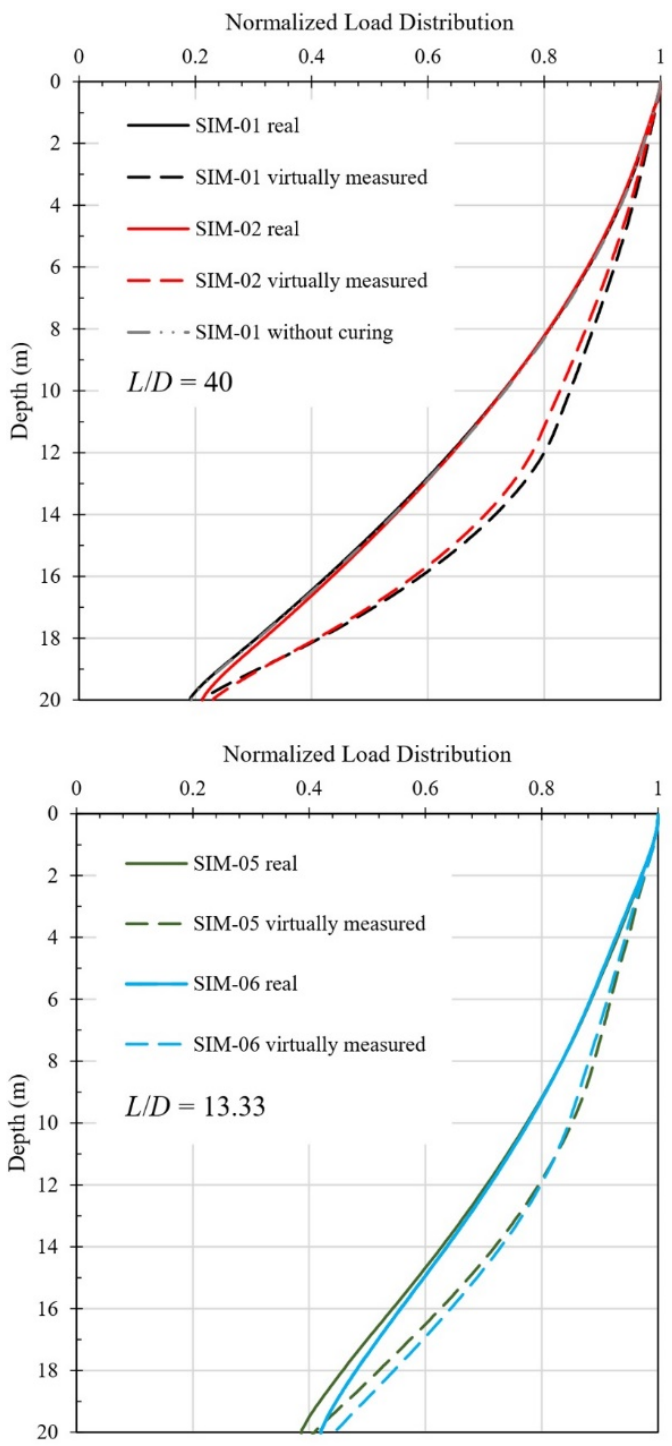
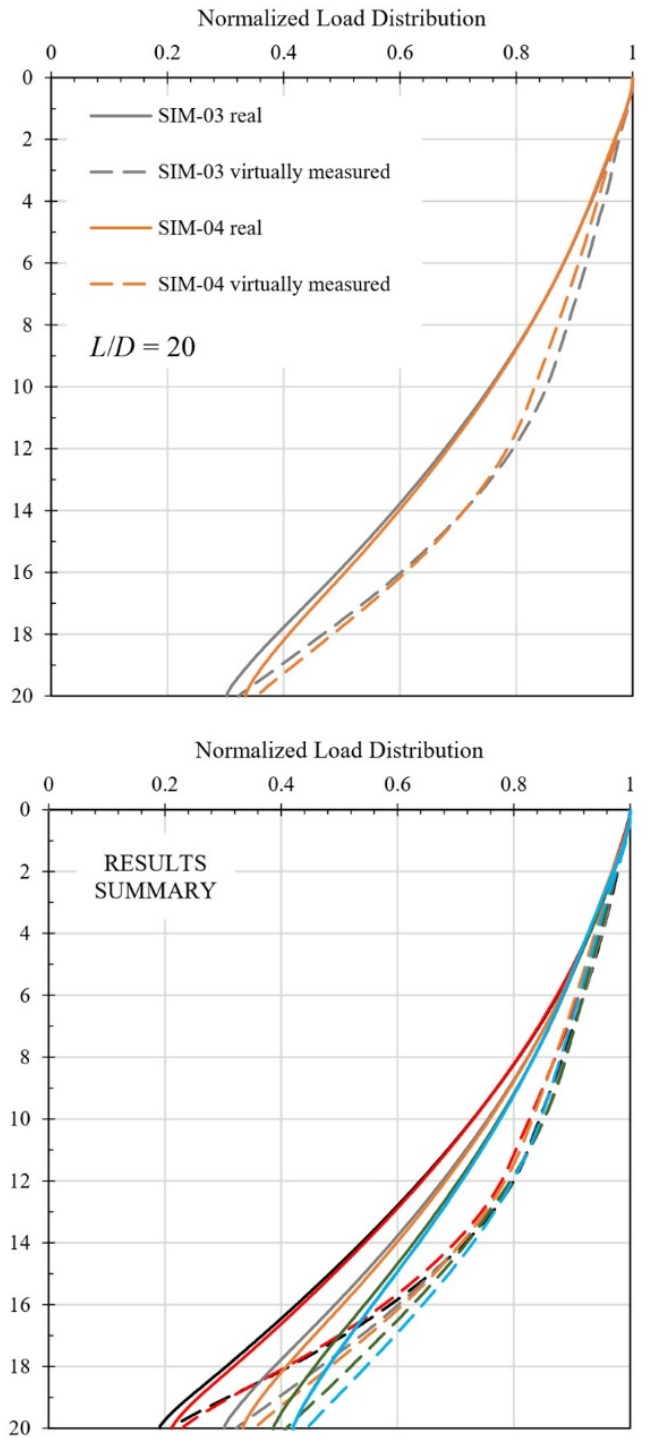

Figure 13. Normalized load distribution curves for $20 \mathrm{~m}$ long non-displacement drilled shafts for analyses with $L / D=40$ (SIM-01 and SIM-02), $L / D=20$ (SIM-03 and SIM-04), and $L / D=13.33$ (SIM-05 and SIM-06).

Going back to unit shaft friction analysis, the pile equilibrium expressed under real and virtual conditions respectively read:

$\int_{0}^{L} \tau_{\text {real }}(z) d z+Q_{b}^{\text {real }}=\gamma_{c} L$

$\int_{0}^{\mathrm{L}} \tau_{\text {virtual }}(\mathrm{z}) \mathrm{dz}+\mathrm{Q}_{\mathrm{b}}^{\text {virtual }}=\gamma_{\mathrm{c}} \mathrm{L}$

where $Q_{b}{ }^{\text {real }}$ and $Q_{b}{ }^{\text {virtual }}$ are the base resistance computed for real and virtual conditions, respectively.

Combining the above Equations 5 and 6 , and observing that $\Delta Q_{b}=Q_{b}{ }^{\text {real }}-Q_{b}{ }^{\text {virtual }} \approx 0$, yield

$\int_{0}^{\mathrm{L}} \tau_{\mathrm{r}}(\mathrm{z}) \mathrm{dz}=-\Delta \mathrm{Q}_{\mathrm{b}} \approx 0$ 
Equation 7 indicate that the distribution of $\tau_{r}$ shall always exhibit a neutral point where a change in signal occurs. The location of this neutral point depends on soil and pile parameters. In homogenous soils, as considered in the present analysis, the neutral point approximately lies at a depth of $z=2 / 3 L$, which is in accordance with previous numerical works performed by Mascarucci [10] and Mascarucci et al. [11].

Numerical predictions for distributions of $\tau_{r}$ and $\tau_{\text {virtual }}$ are in agreement with experimental data measured from instrumented piles, such as the results previously displayed in Figure 3. It is emphasized that experimental works [22]- [24] give evidence that $\tau_{\text {virtual }}$ distribution along depth can significantly differ from the actual $\tau$ distribution, although both yield the same bearing capacity.

The calculated load-displacement curves for each case are presented in Figure 14 with and without consideration of the curing process and associated pre load-step strains.
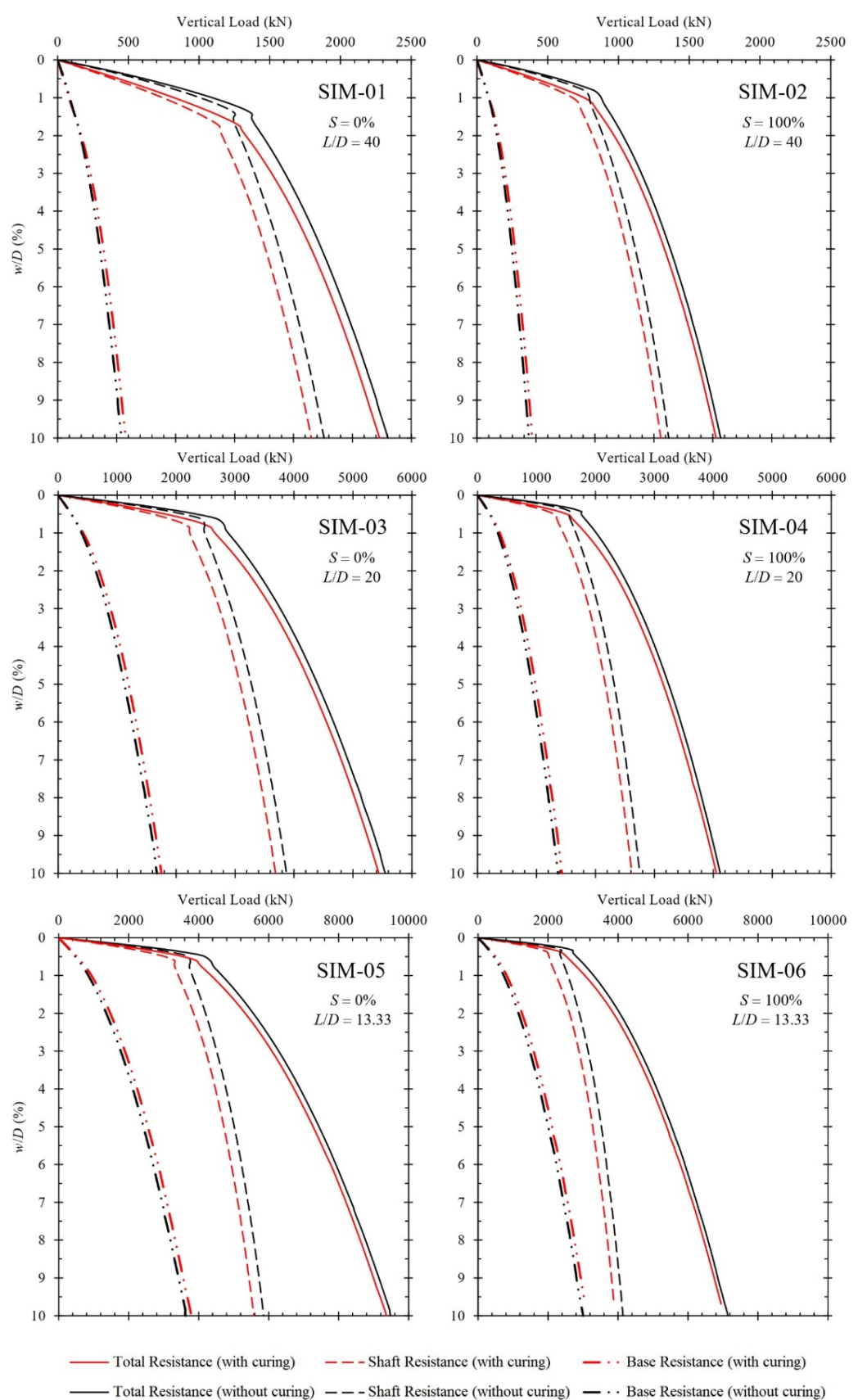

Figure 14. Load-settlement curves for $20 \mathrm{~m}$ long drilled shafts for analyses with $L / D=40$ (SIM- 01 and SIM- 02 ), $L / D=20$ (SIM- 03 and SIM-04), and $L / D=13.33$ (SIM-05 and SIM-06). 
It can be noted from Figure 14 that consideration of curing strains has little effect on the ultimate load $\left(Q_{u l t}\right)$ distribution. The results summarized in Table 3 are in accordance with limit analysis theory [21], as already mentioned when discussing unit shaft friction distribution.

Table 3. Results for the analyses at $w / D=10 \%$.

\begin{tabular}{ccccccc}
\hline Analysis & $\boldsymbol{Q}_{l, w / c}{ }^{*}(\mathbf{k N})$ & $\boldsymbol{Q}_{l, w / c} / \boldsymbol{Q}_{\boldsymbol{l}}$ & $\boldsymbol{Q}_{b, w / c}(\mathbf{k N})$ & $\boldsymbol{Q}_{b} / \boldsymbol{Q}_{b, w / c}$ & $\boldsymbol{Q}_{\boldsymbol{u l t}, \boldsymbol{w} / \boldsymbol{c}}(\mathbf{k N )}$ & $\boldsymbol{Q}_{\boldsymbol{u l t}, \boldsymbol{w} / \boldsymbol{c}} / \boldsymbol{Q}_{\boldsymbol{u l t}}$ \\
\hline SIM-01 & $1,794.37$ & $95.24 \%$ & 481.47 & $93.74 \%$ & $2,275.85$ & $97.45 \%$ \\
\hline SIM-02 & $1,299.62$ & $95.88 \%$ & 389.57 & $94.14 \%$ & $1,689.18$ & $98.08 \%$ \\
\hline SIM-03 & $3,687.05$ & $95.18 \%$ & $1,752.05$ & $95.59 \%$ & $5,439.10$ & $98.03 \%$ \\
\hline SIM-04 & $2,617.98$ & $95.13 \%$ & $1,433.29$ & $95.30 \%$ & $4,051.28$ & $98.38 \%$ \\
\hline SIM-05 & $5,576.58$ & $95.19 \%$ & $3,791.08$ & $95.63 \%$ & $9,367.66$ & $98.77 \%$ \\
\hline SIM-06 & $3,885.15$ & $93.83 \%$ & $3,058.89$ & $98.13 \%$ & $6,944.05$ & $97.22 \%$ \\
\hline
\end{tabular}

*w/c means 'with curing'.

This set of results demonstrates that curing strains slightly affect the ultimate state design of drilled shafts. However, this phenomenon is expected to influence the shaft friction distribution and bearing load-strain behavior at earlier stages, such as loads controlling serviceability limit state.

\section{Influence of concrete curing on design parameters}

The influence of concrete curing on the $K_{s}$ and $\beta$ parameters (related by Equation 1), which control the distribution of shaft friction in conventional pile design, has been evaluated by mean of a series of numerical simulations with consideration for the virtual and real cases. The obtained $K_{s}$ profiles are shown in Figure 15 and computed for an interface friction angle $\delta=29^{\circ}$. It should be recalled that perfect bonding condition at the pile-soil interfaced has been assumed throughout the paper and the interface friction angle is used only to calculated $K_{s}$. The distribution of coefficient $\beta$ can be directly deduced from $K_{s}$ since the soil profile is considered homogeneous with constant interface friction angle $\left(\beta=K_{s} \tan \delta\right)$.

Referring to Figure 15, the following comments may be made to guide engineering design of drilled shafts:

a) The singularity associated with the high values of $K_{s}$ computed in the upper soil layers is reflecting vanishing vertical stresses in this region.

b) Disregarding this upper crust, the values of $K_{s}$ exhibit a slight reduction with depth and rapidly tends to a constant value.

c) Referring to the so-called virtual case, it appears that $K_{s, v i r t u a l}=\tau /\left(\sigma_{v 0}^{\prime} \tan \delta\right)$ with $\delta=\phi$ constant along the depth and $K_{s, \text { virtual }}=\sigma_{h}^{\prime} / \sigma_{v 0}^{\prime}$ exhibit close profiles along the region laying above the neutral point, whereas they progressively deviate from each other as depth increases. Except in a narrow zone located beneath the upper surface, the ratio $K_{s, v i r t u a l}=\sigma_{h}^{\prime} / \sigma_{v 0}^{\prime}$ reveals close to $K_{0}$ value. The latter can therefore be conveniently used in drilled pile design to characterize the initial stress state.

d) The estimates of $K_{s, \text { real }}$ and $K_{s, \text { virtual }}$ for the earth pressure coefficient could significantly differ, indicating that disregarding the concrete curing effect amounts, the initial horizontal stress distribution at shallow depths tends to be underestimated.

e) $K_{s}$ is a valuable design parameter for shaft resistance, but it has no physical meaning limiting $K_{s}$ value by active $\left(K_{a}\right)$ and passive $\left(K_{p}\right)$ earth pressure coefficient values, given that $K_{s}$ always refers to the initial condition and not the current condition in the soil.

f) The pile slenderness $L / D$ has only some effect on $K_{s}$ distribution close to the upper surface, without affecting its asymptotic value.

g) For the two limiting saturation conditions $(S=0 \%$ and $S=100 \%)$ evaluated in this paper, it is found from the numerical simulations that saturation has qualitatively similar effects on $K_{s}$ than $L / D$.

\section{CONCLUSIONS}

It is widely accepted that load test performed at relatively large prescribed displacements to reach the ultimate limit state is the most reliable procedure to analyze the behavior of piles, although technological factors, such the method of construction, are expected to affect the measured response. 

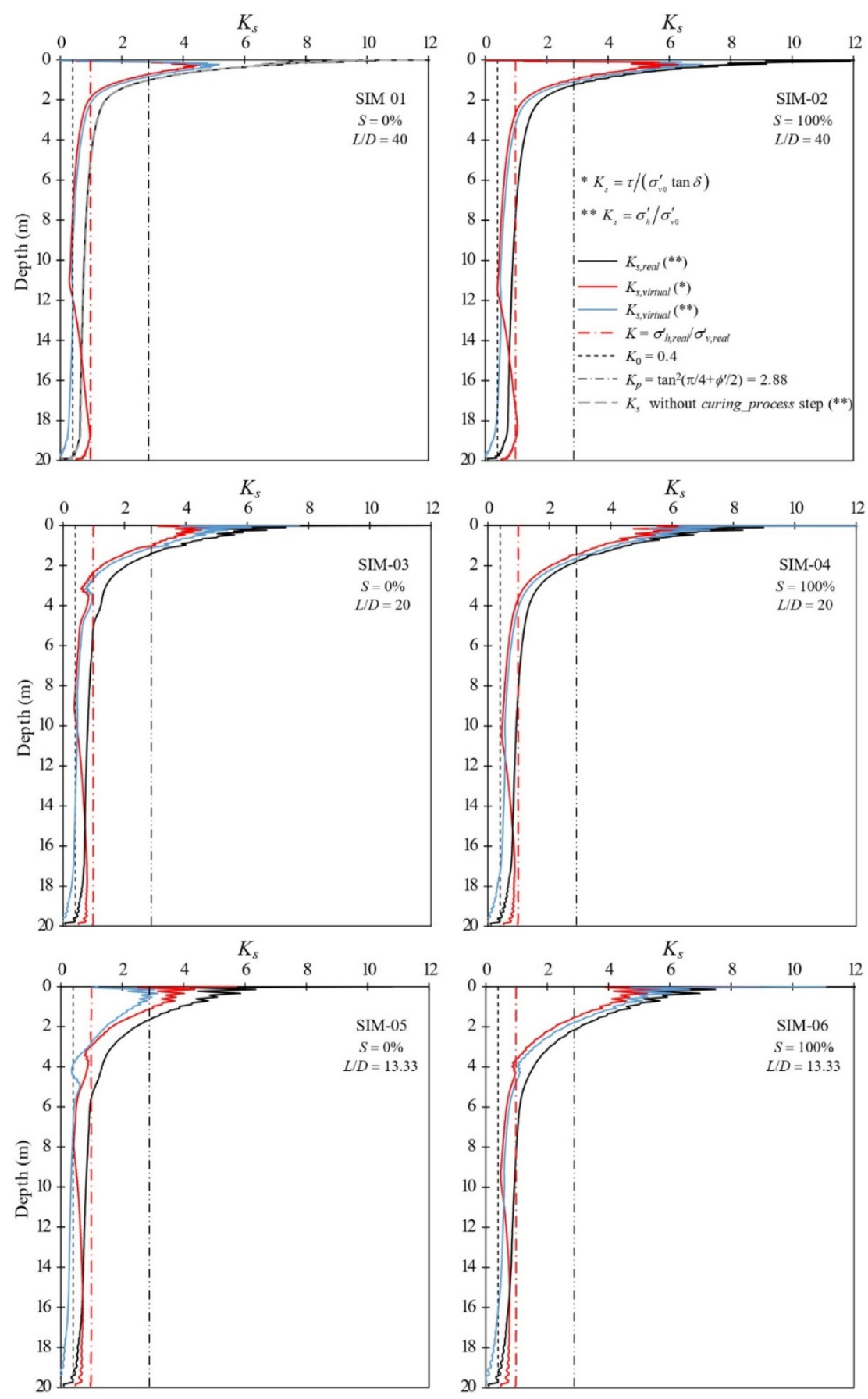

Figure 15. $K_{s}$ distribution along pile shaft.

Based on these premises, numerical analyses were performed to assess the effect of curing process on the shaft friction regarded as a major parameter in pile design. The numerical analyses indicate that ultimate resistance is in fact not significantly affected by the curing process-imposed strains. The same trend is observed for base and lateral mobilized resistances.

The volumetric strains in the pile due to concrete curing induce contraction in the whole pile, generating downward relative movements in the upper part of the pile and upward relative movements in its lower part. This phenomenon explains the errors that can be introduced by "zeroing" the instruments immediately before starting a load test. 
In regard to pile analysis and design, the distribution of the stress parameter $K_{s}$ along the pile shaft, classically used to evaluate ultimate shaft friction profile, could be significantly affected by concrete curing while pile slenderness ratio or saturation conditions in homogeneous soils are not.

\section{ACKNOWLEDGEMENTS}

The authors wish to explicit their appreciation to CAPES and CNPq for the support provided to the research group.

\section{REFERENCES}

[1] R. D. Rieke and J. C. Crowser, "Interpretation of pile load test considering residual stresses," J. Geotech. Eng., vol. 113, no. 4, pp. 320-334, Apr 1987, http://dx.doi.org/10.1061/(ASCE)0733-9410(1987)113:4(320).

[2] B. H. Fellenius, Basics of Foundation Design. Vero Beach: Pile Buck Int., 2017.

[3] C. F. Leung, R. Radhakrishnan, and Y. K. Wong, "Observations of an instrumented pile-raft foundation in weak rock," Proc.- Inst. Civ. Eng., vol. 84, no. 4, pp. 693-711, Aug 1988.

[4] C. Viggiani and F. Vinale, "Comportamento di pali trivellati di grande diametro in terreni piroclastici," Riv. Ital. Geotec., vol. 2, pp. $59-84,1983$.

[5] D. S. Pennington, "Cracked? Exploring post construction evidence in the interpretation of trial pile data," Proc. Inst. Civ. Eng. Geotech. Eng., vol. 113, no. 3, pp. 132-143, Jul 1995, http://dx.doi.org/10.1680/igeng.1995.27809.

[6] J. B. Burland, "Shaft friction of piles in clay," Gr. Eng., vol. 6, no. 3, pp. 30-42, 1973.

[7] P. W. Mayne and F. H. Kulhawy, "Ko - OCR relationships in soil," J. Geotech. Eng. Div., vol. 108, no. 6, pp. 851-872, 1982.

[8] F. H. Kulhawy, "Drilled shaft foundations," in Foundation Engineering Handbook, H.-Y. Fang, Ed., Boston, MA: Springer US, 1991, pp. 537-552. http://dx.doi.org/10.1007/978-1-4615-3928-5_14.

[9] F. H. Kulhawy, "Limiting tip and side resistance - fact or fallacy," in Analysis and Design of Pile Foundations, J. R. Meye, Ed., New York: American Society of Civil Engineers, 1984, pp. 80-98.

[10] Y. Mascarucci, Un Nuovo Approccio per la Valutazione della Resistenza Laterale dei Pali Trivellati in Terreni Sabbiosi. Roma: La Sapienza, 2012.

[11] Y. Mascarucci, A. Mandolini, and S. Miliziano, "Effects of residual stresses on shaft friction of bored cast in situ piles in sand," J. Geo-Engineering Sci., vol. 1, no. 1, pp. 37-51, 2013, http://dx.doi.org/10.3233/JGS-13009.

[12] Itasca Consulting Group. US Minneapolis. "FLAC constitutive models". 2020. [Online]. Available: https://www.itascacg.com/software/flac-constitutive-models

[13] D. Loukidis and R. Salgado, "Analysis of the shaft resistance of non-displacement piles in sand," Geotechnique, vol. 58, no. 4, pp. 283-296, 2008, http://dx.doi.org/10.1680/geot.2008.58.4.283.

[14] M. F. Randolph and C. P. Wroth, "Analysis of deformation of vertically loaded piles," J. Geotech. Eng. Div., vol. 104, no. 12, pp. 1465-1488, 1978.

[15] Associação Brasileira de Normas Técnicas, Design of Structural Concrete-Procedure, NBR 6118:2014, 2014.

[16] F. Han, R. Salgado, M. Prezzi, and J. Lim, "Shaft and base resistance of non-displacement piles in sand," Comput. Geotech., vol. 83, pp. 184-197, Mar 2017, http://dx.doi.org/10.1016/j.compgeo.2016.11.006.

[17] International Federation for Structural Concrete, (fib) Model Code for Concrete Structures 2010, 2013.

[18] E. E. Holt, "Early age autogenous shrinkage of concrete," Ph.D. dissertation, Tech. Res. Cent. Finland, Espoo, 2001.

[19] P. K. Mehta and P. J. M. Monteiro, Concrete-Microstructure, Properties, and Materials, 3rd ed. New York: McGraw-Hill, 2006.

[20] B. Halphen and J. Salençon, Élastoplasticité. Paris: Press. Ec. Natl. Ponts et Chaussées, 1987.

[21] J. Salençon, Calcul à la Rupture et Analyse Limite. Paris: Press. Ec. Natl. Ponts et Chaussées, 1983.

[22] A. Altaee, B. H. Fellenius, and E. Evgin, "Load transfer for piles in sand and the critical depth," Can. Geotech. J., vol. 30, no. 3, pp. 455-463, 1993, http://dx.doi.org/10.1139/t93-039.

[23] T. A. B. P. Pereira, “Análise e dimensionamento de estacas sujeitas a compressão axial: aplicações na região administrativa especial de Macau,” M.S. thesis, Univ. Porto, Porto, 2012.

[24] A. S. Vesić, "Tests on instrumented piles - Ogeechee River site," J. Soil Mech. Found. Eng. Div., vol. 96, no. SM2, pp. 561-584, 1970.

Author's contributions: Contribution description of each co-author for the study; Conceptualization: Fernando Schnaid and Augusto Bopsin Borges; Supervision: Renato Vaz Linn, Fernando Schnaid and Samir Maghous; Writing: Augusto Bopsin Borges, Fernando Schnaid and Samir Maghous; Data curation, formal analysis and methodology: Augusto Bopsin Borges, Renato Vaz Linn and Samir Maghous.

Editors: José Marcio Calixto, José Luiz Antunes de Oliveira e Sousa, Guilherme Aris Parsekian. 